\title{
OBITUARY
}

\section{E. FORD}

Ebenezer Ford was born on 22 September 1890 at Hove, Sussex, and died on 14 October 1974 at the age of 84 . His father, George Horace Ford, was a man of insatiable intellectual curiosity and was a great stimulus to his sons. He took them on walks to 'explore' the countryside of Sussex, including the sea shore, which much interested 'Ebb', as he was known. Both sides of the family came from yeoman non-conformist stock, which instilled into him a keen sense of duty and desire to serve the public. Ebb was much involved in country affairs and had many opportunities of taking part in Wealden farm life. He was thus essentially an open-air boy with a growing interest in nature.

He was educated at Varndean School (then known as York Place), where he was strong on science. His senior science master told his brother that an inspector once came into the laboratory and asked why it was that Ebb seemed to be playing about instead of working hard. The master replied, 'Ask him anything you like.' The inspector did and was satisfied. It was only that Ebb had finished his experiment and work long before the others and was then occupying his own time. He was a leader in all forms of sport and excelled at cricket, soccer and swimming, and later at hockey.

He went for two years to Brighton Technical College and in 1911 entered Imperial College (then the Royal College of Science) for a general science course. There he came especially under the influence of $\mathrm{E}$. W. McBride and C. Dobell.

In 1913 he was awarded a Sarah Marshall Exhibition for research work as a Huxley Scholar. The same year he was appointed Assistant Naturalist at the Plymouth laboratory. He travelled down from London for his interview in the same compartment as a fellow passenger with whom he conversed on science and biology. Later he discovered that it was E. J. Allen, his future Director!

Ford's stay at Plymouth was quickly curtailed by the outbreak of war in 1914. He enlisted in the Sussex Yeomanry. When this was dismounted he was commissioned in the Royal Fusiliers and (Reserve) Battalion of the London Regiment. He saw active service in the fierce fighting in France and was wounded at Passchendaele. After rehabilitation he became a musketry officer, and in fact remained a first-rate shot almost up to the time of his death. He never lost the trim and upright carriage of his army days.

He returned to Plymouth in 1919 as Assistant Naturalist, to be promoted soon to Fisheries Naturalist. In 1935 he was appointed Assistant Director of the laboratory, in which post his flair for detailed administration could be fully used.

His scientific career was again interrupted by the Second World War. At first he served in 'D' Company of the 15th Battalion (Devonshire) Home Guard. In November 1941, feeling that he should be nearer active war employment, he joined the R.A.F.V.R. and became a valued colleague with me in Air Intelligence in the Air Ministry in London.

On 1 April 1949 Ford was appointed Director of the Millport Laboratory in succession to the late Richard Elmhirst and became the first full-time Secretary of the Scottish Marine Biological Association. His administrative ability and experience were of great 
value to the Association at a time of major reorganization and the incorporation of the Oceanographic Laboratory in Edinburgh into the Association.

He retired from the Millport Directorship on 31 March 1956 and returned to his home country in Sussex, naming his house 'Keppel' after the pier at Millport.

Ford's first scientific paper was published in 1913 in the Archiv für Protistenkunde. In this he described the nuclear division in a Limax amoeba brought by Dobell from Cambridge. Using Dobell's method of staining he demonstrated the existence of achromatic caps during division.

On his appointment to the Plymouth laboratory in 1913 he first started to work on the young stages of fish under the guidance of R. S. Clark. He was a natural artist and his first published work in this field consisted of drawings of postlarval stages of Zeus faber, Capros aper and Pegusa lascaris illustrating a paper by Clark in Volume 10 of the Association's Journal. Others of his illustrations appeared in a later paper by Clark in Volume 12; these were postlarvae of Microstomus kitt, Microchirus variegatus, Serranus cabrilla, Cepola rubescens and Trachinus draco. Ford also did a beautiful drawing of the 'postpuerulus' stage of the rock lobster, Palinurus, which appeared in a paper by Orton \& Ford in Proc. Zool. Soc. 1933.

On his return to Plymouth after the 1914-18 war he at first continued working on young fish and described the postlarval stages of sand eels, blennies and wrasses. He also kept a leptocephalus stage of the conger eel alive through metamorphosis. He next made a survey of the biology of the five species of dogfish occurring off Plymouth, fish which had then become important commercially in the fish-and-chip industry. He added much to our knowledge on the development of the embryos, the size of the fish at sexual maturity, and the proportions of the sexes. For this research he was a frequent visitor to the fish quay and was always to be very much at home in the company of fishermen.

In 1922 he undertook a study of the benthic animal communities off Plymouth, using the $\frac{1}{10} \mathrm{~m}^{2}$ grab for comparison with the results of Petersen in Danish waters. This was followed by an investigation of the growth of molluscs in relation to the food supply of fish. He followed the growth of individuals of some species, such as Spisula, using length measurements and dry weights, and related the growth rings on the shells to the winters in Syndosmya and Spisula. This investigation, which forms a valuable record of conditions at the time, provided evidence of Ford's love for numerical analysis.

At the end of 1924 he started his major work at Plymouth on the herring. At that time there was an important commercial fishery during the winter months, attracting large numbers of east-coast steam-drifters and Cornish motor-drifters which together formed a fishing fleet of between two and three hundred vessels. His results were published in nine papers which provide an interesting overall picture of the kinds of observations required for a fishery investigation. His first paper on the methods of collection and of treatment of the data was a model of concise information, detailing exactly how the samples were collected and treated, drawing attention to the effects on the results of such factors as net selection and variation in vertebral counts. For the latter he gave a simple and readable account of the need for statistical treatment. He had already been discussing with his brother, then Lecturer in Economics at the University of Newcastle, the application of statistical methods to human and fish populations. It should be realized that this was just 
about the time that R. A. Fisher was concerned with the mathematical treatment of data acquired in biological research, culminating in his textbook on Statistical Methods for Research Workers, published in 1925. Ford in all his research was very interested in the use of numbers.

Aspects covered in his research on the herring were:

(1) Numbers of vertebrae, for which he compared samples of Plymouth herring with those from Milford Haven, Padstow, Newlyn, Mevagissey, Brixham, Brighton and Lowestoft. He showed that there was not a rigid 'type', but that there was a gradual shift in the average numbers of vertebrae as one went eastward up the Channel, the average number decreasing with decreasing salinity. I can well remember the constant smell of boiling herring as one entered the laboratory buildings. Boiling took place in the receiving room at the left of the entrance and Ford had developed things to a fine art so that the fish were cooked to the point that the flesh could be removed without the skeleton falling apart.

(2) Scale readings, for which he designed a very simple apparatus using a camera bellows mounted above a microscope, of which he published an excellent perspective drawing.

(3) Stages of maturity.

(4) A comparison of the catches and numbers of boats of different categories employed in the winter fisheries from 1924 to 1929.

(5) The growth of young herring in the Tamar estuary.

(6) Experiments on the effects of different salinities on the development of the egg disclosing a surprisingly wide tolerance.

(7) Studies to show the differential growth as the larva developed to the adolescent stage. He illustrated this with ingenious models constructed of different lengths of rigid and elastic tape. By lengthening these he could demonstrate the changing positions of the dorsal fin, pelvic fin and anus in relation to one another - a diagnostic character for the identification of the species.

All the results were summarized in a final paper which analysed the commerical aspects of the fishery in greater detail. He considered at length the significance of the composition of the population of herring as indicated by such factors as vertebral numbers and growth. Among other things he compared wind strengths with catches and showed that catches apparently were greater following immediately after a gale. This study was undertaken as a result of observations made earlier by Howard Dunn on the Mevagissey fishery.

This great herring fishery died out in the early 1930 , probably due to climatic change, and it is fortunate that thanks to Ford's wide interest and detailed work that it is now so well documented.

In his counting of vertebrae he had constantly noticed slight abnormalities in the formation of vertebrae first drawn to attention in a joint paper with $\mathrm{H}$. $\mathrm{O}$. Bull in 1926. In a paper published in 1933 in the fournal du Conseil he showed that the numbers of abnormalities were surprisingly high and that this might well affect the validity of vertebral counts. Abnormality was especially marked in the numbers of 'tail' vertebrae.

In addition to his work on the early stages of the herring Ford investigated in detail the 
differential growth of the larva to adolescence in two other clupeid fish, the pilchard and sprat. In these species also the positions of the dorsal and pelvic fins are diagnostic characters, especially that of the pelvic in relation to the pylorus.

In his herring investigations Ford had spent much time on the quayside talking to fishermen. He had always been attracted to the more practical side of scientific research and his general interest in the economic aspects of the fishing industry led to his being selected as Buckland Lecturer for 1936, for which he chose as his subject 'The Nation's Sea-fish Supply'. In this he presented in very readable form the necessity for the SeaFishing Industry Act of 1933 restricting fishing in northern waters, the effects of net mesh size on the natural fish populations, and the need to regard fish in the sea as livestock to be exploited with care.

A fisherman with whom he had much contact was Howard Dunn of Mevagissey, and he gave an interesting lecture on the life of Howard's father, Matthias Dunn, a famous old naturalist fisherman. This was published in the Transactions of the Plymouth Institution. He also wrote popular articles in the Fishing News under the pen-name of 'Quibbon'.

As a result of his interest in the herring backbone he made a study of the vertebral variation of a number of species spread over the different Orders of teleostean fish. He found in a number of species a high percentage of abnormality. He was especially interested in the form of the vertebral column in relation to function, under the headings, as, a functional neck, the operative base of the caudal fin, support for the median fins, the housing for the central nervous system, the housing of blood vessels, a seat of attachment for the muscles, and its structure in relation to swimming movements. A number of other aspects were considered and the paper was accompanied by a series of fine photographs of the backbones of thirty-two species of fish.

In October 1935 a discussion was held at Lowestoft between investigators of eleven countries represented on the International Council for the Exploration of the Sea on the co-ordination of the results of herring research. Among the resolutions of this meeting was the following: 'It is recommended that a co-operative study be undertaken on the practicability of utilizing a count of separate portions of the vertebral series in such a way as to draw distinctions between morphologically distinguishable groups with a minimum of labour and material. Mr Ford accepted an invitation to prepare a scheme. Professor R. A. Fisher consented to act in an advisory capacity.' As a result of this a preliminary paper was published by Ford in 1941 describing in detail the vertebral numbers in different parts of the backbone and their variations, but by now the war had intervened.

When he returned to Plymouth after the war he continued his research on skeletal structures, dealing especially with the bones of the neurocranium of twenty gadoid species. This held promise of producing most interesting results but he left to take up his post at Millport and never published.

I first met Ford in September 1922 when I was sent to Plymouth preparatory to studying the eggs and young stages of fish in Egyptian waters. I was introduced to the subject by R. S. Clark, and Ford was working in the same room, which formed part of a building since demolished to make way for the library. He was then working on his benthic sampling, but was very helpful and kind to me, as he was always to his colleagues. I 
gained much from his guidance; especially one learnt from him to be precise and meticulous in detail. I have vivid recollections of outings with him when I joined the staff, such as fishing for bass at night in the dockyard for the aquarium and pushing the catch back on a hand-cart in pouring rain, and fishing with a special net he constructed to catch animals under a light in the Sound on the 'Gammarus' in the dark.

He was the last surviving member of the pre-1920 staff of the Plymouth laboratory and his going marks the end of a period of the history of the Marine Biological Association.

For his services to marine science he was awarded the O.B.E. While in Scotland he was elected a Fellow of the Royal Society of Edinburgh.

He married in August 1916 Alice Gurr, a member of a family with a long-standing friendship with the Ford family. It was a tragic blow for Ebb when she died in January 1950 before he had completed his first year as Director of the Millport laboratory. They had one daughter, now Mrs Joan $M$. Stacey, to whom I am indebted for much information. I am also especially grateful to his brother, Emeritus Professor P. Ford, for his help in supplying the story of his boyhood.

F. S. RUSSELL

\section{LIST OF E. FORD'S PUBLISHED WORKS}

1914. On the nuclear division of a free-living limax amoeba (Amoeba tachypodia Gläser). Archiv für Protistenkunde, 34, 190-7.

1920. Note on a leptocephalus stage of the conger. Fournal of the Marine Biological Association of the United Kingdom, 12, 249-52.

1920. The economic value of dogfish. Fish Trades Gazette, 20 March, 1920, 16 pp.

1920. The number of pyloric caeca in the herring. (Supplement to 'An account of the researches on races of herrings carried out by the Marine Biological Association at Plymouth, 1914-15.') Fournal of the Marine Biological Association of the United Kingdom, 12, 325-31.

1920. The post-larval stages of Ammodytes species captured during the cruises of S.S. 'Oithona' in Plymouth waters in the year 1919. Fournal of the Marine Biological Association of the United Kingdom, 12, 241-8.

1921. A contribution to our knowledge of the life-histories of the dogfishes landed at Plymouth. Fournal of the Marine Biological Association of the United Kingdom, 12, 468-505.

1922. On the post-larvae of the wrasses occurring near Plymouth. Fournal of the Marine Biological Association of the United Kingdom, 12, 693-9.

1922. On the young stages of Blennius ocellaris L., Blennius pholis L., and Blennius gattorugine L. Fournal of the Marine Biological Association of the United Kingdom, 12, 688-92.

1923. Animal communities of the level sea-bottom in the waters adjacent to Plymouth. Fournal of the Marine Biological Association of the United Kingdom, 13, 164-224.

1923. The preparation of dogfish for market. Fishery Board of Scotland, 8 pp. London: H.M.S.O.

1925. On the growth of some lammelibranchs in relation to the food-supply of fishes. Fournal of the Marine Biological Association of the United Kingdom, 13, 531-59.

1926 (with H. O. Bull). Abnormal vertebrae in herrings. Fournal of the Marine Biological Association of the United Kingdom, 14, 509-17.

1928. Herring investigations at Plymouth. I. Methods of collection and treatment of data. Fournal of the Marine Biological Association of the United Kingdom, 15, 237-66.

1928. Herring investigations at Plymouth. II. The average number of vertebrae for herrings from the English Channel and the south-east of Ireland. Fournal of the Marine Biological Association of the United Kingdom, 15, 267-78.

1928. Herring investigations at Plymouth. III. The Plymouth winter fishery during the seasons 1924-25, 1925-26 and 1926-27. Fournal of the Marine Biological Association of the United Kingdom, 15, 279-304. 
1928. Herring investigations at Plymouth. IV. The growth of young herrings in the neighbourhood at Plymouth. Fournal of the Marine Biological Association of the United Kingdom, 15, $305-19$.

1929. Herring investigations at Plymouth. V. The Plymouth winter fishery during the season 1927-28. Fournal of the Marine Biological Association of the United Kingdom, 16, 1-24.

1929. Herring investigations at Plymouth. VI. Winter herrings caught off the Sussex coast and in the Great West Bay during the years 1924 to 1927. Journal of the Marine Biological Association of the United Kingdom, 16, 25-42.

1929. Herring investigations at Plymouth. VII. On the artificial fertilisation and hatching of herring eggs under known conditions of salinity, with some observations on the specific gravity of the larvae. Fournal of the Marine Biological Association of the United Kingdom, 16, 43-8.

1930. Herring investigations at Plymouth. VIII. The transition from larva to adolescent. fournal of the Marine Biological Association of the United Kingdom, 16, 723-52.

1930. Some abnormal fishes received at the Plymouth laboratory. Fournal of the Marine Biological Association of the United Kingdom, 17, 53-64.

1931. Changes in length during the larval life and metamorphosis of the freshwater eel (Anguilla vulgaris Turt.). Fournal of the Marine Biological Association of the United Kingdom, 17, 9871000.

1931. Growth in length during the transition from larva to adolescent in the pilchard and sprat. Fournal of the Marine Biological Association of the United Kingdom, 17, 977-85.

1933. An account of the herring investigations conducted at Plymouth during the years from 1924 to 1933. Fournal of the Marine Biological Association of the United Kingdom, 19, 305-84.

1933. Marine biology and the sea fisheries. British Sea Anglers'Society's Quarterly, 26, 23-7, $50-6$.

1933. The 'number of vertebrae' in the herring and its variation. Fournal du Conseil permanent international pour l'Exploration de la Mer, 8, 211-22.

1933. (with J. H. Orton). The post-puerulus of Palinurus vulgaris Latr. Proceedings of the Zoological Society of London, 1933. part 1, pp. 181-8.

1934. Science and State regulation of the sea fisheries. Nature, London, 134, 593-4.

1935. The advance of herring research. Nature, London, 136, 896-7.

1937. Matthias Dunn; the fisherman naturalist of Mevagissey: résumé of a lecture by $\mathrm{Mr} \mathrm{E}$. Ford (read December 15th, 1933). Annual Reports and Transactions of the Plymouth Institution and Devon E Cornwall Natural History Society, 17, 264-72.

1937. The nation's sea-fish supply: Being the Buckland Lectures for 1936. $112 \mathrm{pp}$. London: Edward Arnold.

1937. Vertebral variation in teleostean fishes. Fournal of the Marine Biological Association of the United Kingdom, 22, 1-60.

1941. Vertebral variation in teleostean fishes. II. The herring (Clupea harengus L.). Fournal of the Marine Biological Association of the United Kingdom, 25, 151-72.

1946. Vertebral variation in teleostean fishes. III. Isospondyli. Fournal of the Marine Biological Association of the United Kingdom, 26, 390-7.

1950. Fish bones. Proceedings of the Royal Philosophical Society of Glasgow, 75, 1-9. 